\title{
The Role of Culture and Belief Systems in Shaping Customary Land Reform
}

\author{
Austine Ng'ombe ${ }^{1} \&$ Anthony Mushinge ${ }^{1}$ \\ ${ }^{1}$ Department of Real Estate Studies, School of the Built Environment, Copperbelt University, P.O. Box 21692, Kitwe, \\ Zambia \\ Correspondence: Austine Ng'ombe, Department of Real Estate Studies, School of the Built Environment, Copperbelt \\ University, P.O. Box 21692, Kitwe, Zambia \\ Received: July 2, $2014 \quad$ Accepted: July 31, $2014 \quad$ Available online: October 10, 2014 \\ doi:10.11114/ijsss.v2i4.552 \\ URL: http://dx.doi.org/10.11114/ijsss.v2i4.552
}

\begin{abstract}
In their quest for economic development through increased private investment, many developing countries are reformulating land policies to pave way for the transformation of communal land rights into private property. However, these customary land reform efforts have often been frustrated by indigenous people who feel such proposals threaten rural livelihoods and undermine the traditional political structures. Most of the research on this subject has focused on whether, how and/or to what extent the objectives of land reforms (e.g. tenure security and hypothecation) have been achieved. However, there is a lack of scholarly research on how and why indigenous people's cultural perspectives and belief systems on land (can) undermine progress on customary land reform. The paper examines and shows how customary land reform aspirations can be undermined by not only the ambiguity of national legal frameworks and lack of participation of local communities in the design of land reform policies/law, but also the indigenous people's long-standing cultural perspectives/belief systems on customary land (reform). We recommend that more innovative ways and further research are needed to achieve land reform and economic development. This, however, should take on board the cultural aspirations of the indigenes' way of life, belief systems and values.
\end{abstract}

Keywords: customary land reform, customary land rights, leaseholds, indigenous people, Zambia

\section{Introduction}

Customary land - which constitutes well over $70 \%$ of all land in developing countries - is said to have a huge agricultural potential. Engagement in agricultural activities is in turn said to have the potential of raising the living standards of communities by, for example, selling agricultural products. However, more than $70 \%$ of customary landholders themselves are nonetheless reported to be still living on less than a dollar a day (Deininger, 2003). The levels of poverty in these rural areas has generated impetus from governments and the outside world to seek best ways of transforming rural (and in other cases peri-urban) land into a supposedly more productive asset in order to eradicate poverty by attracting private investment thereby facilitating attainment of economic growth and sustainable development. It is widely believed that this would be achieved by enhancing security of tenure by way of holding title deeds, stimulating land markets, as well as enabling people's access to formal credit (de Soto, 2000). Consequently, customary land reform has engrossed many policy makers, analysts, development agencies and researchers as the subject continues to attract global attention and intense debate (for example see Ng'ombe \& Keivani, 2013). Despite the voluminous amount of literature on land reform, these literatures are largely on investigating whether, how and/or to what extent the objectives of a particular customary land reform programme may have been achieved (e.g. see Payne, Durand-Lasserve \& Rakodi, 2009). These objectives are, by and large, increased tenure security, agricultural 
productivity, environmental imperative and access to formal credit (Deininger, 2003; de Soto, 2000). Nonetheless, there is little research on how traditional perspectives on land can affect or shape customary land reform, and how this can in turn undermine economic growth and sustainable development aspirations as promoted by the international community. The paper uses international literature, complemented by personal experience and qualitative data from North-western province of Zambia to investigate how customary land reform as pursued by Zambia through its 1995 Lands Act can be undermined by indigenous people's cultural perspectives, including belief systems and the role of ancestors in land administration.

\section{Background to (Customary) Land Reform}

To understand customary land reform, it is important to first define the concept of land tenure. Land tenure derives from the Latin word 'tenere' which means 'to hold' (Barnes, 1986). Thus land tenure describes:

The system of access to and control over land and related resources. It defines the rules and rights which govern the appropriation, cultivation and use of natural resources on a given space or piece of land. Strictly speaking, it is not land itself that is owned, but rights and duties over it (DfID, 2007: 27).

On the basis of this definition, 'land reform' defines changing the mode by which land is held (Manji, 2006). Consequently, customary land reform entails changing the institutions governing the use of traditional land and how rights to such lands are disposed of. Manji (2006) argues that all land reforms can either be redistributive or tenurial land reforms. Redistributive land reform is about redistributing land, transferring it from those with larger pieces of land to those without, or vice versa. On the other hand, tenurial land reform is about changing the institutions/rules surrounding the use of land. Borras $(2005,2002)$ has classified land reform into state-led agrarian reforms (SLAR) and market-led agrarian reforms (MLAR). SLAR is a reform in which the state takes a leading role in the redistribution of land rights with the major aim being to protect smallholder farmers by ensuring that they benefit from the land reform. MLAR, on the other hand, is based on the concept of 'willing-seller, willing buyer', where the distribution of land is purely done on the basis of the open market. The willing seller, willing buyer approach has been used as a basis for land reform in countries like South Africa and Namibia (van Hecke, 2001).

On the basis of the above classification, land reform can thus be argued from economic and social theoretical fronts. The economic case is enshrined within the widespread belief that land reform would bring about an efficient market economy, particularly land and credit markets (Borras, 2002, 2005). By and large, market-based land reforms are based on Garrett Hardin's (1968) classic metaphor - the tragedy of the commons, which perceives the 'commons' as a recipe for over-exploitation of a resource. The argument behind the tragedy of the commons is that land users, acting independently and rationally (i.e. driven by the promise of profit/benefit), will ultimately deplete a commons even when it is very clear to each one of them that this is not in any one's long term interest to happen. If we consider Hardin's (1968) example of a grazing land, this happens because while the benefits of maximising the number of cattle on a commons (grazing land) accrue to individuals, the costs of adding extra animals are shared among all the herders. In the long run, this would degrade the commons.

On the other hand, the social argument for land reform is based on equitable distribution of resources. It is believed that free market leads to poverty. The socially-inclined land reforms are mainly distributive in nature, with central government control playing a crucial role. The reforms are based on the assumption that left to themselves, markets fail to transfer enough land to meet the needs of the poor people (Cotula, 2004). These reforms have been applied mainly in countries that seek to correct historical injustices in land distribution (van Hecke, 2001). Examples include restitution programmes where, like in South Africa, land has been allocated to those who were denied access during the apartheid era (Quan, 2008).

The rationale behind customary land reform, therefore, revolves around the quest to eradicate poverty which is widespread in many developing countries (Deininger, 2003). Generally speaking, it is argued that customary tenure 
systems are inconsistent with modern economic markets and yet it is the free market economy that can help eradicate poverty (Deininger, 2003; Barrows \& Roth, 1990). Mulolwa (2006) observes that customary tenure has become a target for transformation because it is perceived to be insecure, it discriminates against women, lacks individual ownership of land, causes environmental degradation, and it embodies weak institutions and management structures. Drawing on Leonard and Longbottom (2000), Place (2009) and Place and Otsuka (2002), among others, the case for customary land reform can broadly be discussed under seven key themes as summarised in table 1.

Table 1. Arguments for customary land reform

Justification Explanation

1.Security of tenure

Defined as a state of feeling safe in holding land, security of tenure can be achieved by holding a title deed.

2.Access to formal

A titled piece of land can be used as security against a loan by using the title deed

credit

3. Land market

4.Agricultural

productivity

5.Increased

investment

6 Farm size \&

efficiency

7.Environmental

imperative

A title deed stimulates land markets because it is easier to ascertain land ownership

Transformation of customary into private land leads to increased farm productivity

Security of tenure is critical in determining the level of investment the owner can make on the land. Increased tenure security incentivises the owner to invest more on land.

Larger farms are more productive than smaller ones

However, while customary tenure is despised by its critics for reasons highlighted in table 1 above, others are in favour of the traditional tenure system. The security of tenure argument, for instance, is dismissed by a number of writers on the basis that security of tenure on customary land exists regardless of the existence of a title deed (e.g. Payne, Durand-Lasserve \& Rakodi, 2009; Mulolwa, 2006; van der Molen, 2002). In fact, empirical evidence shows that the perception of security, and not necessarily the acquisition of a title, is actually more important (Payne, Durand-Lasserve $\&$ Rakodi, 2009). Moreover, others have argued that titled land is a wasting asset because it becomes more insecure as the lease nears the expiration date (Bruce, Kachamba \& Hansungule, 1995). Similarly, reasons of productivity, increased investment and access to credit have been contested. There is growing evidence to suggest that people in developing countries are averse to hypothecation because they believe that debt is another way governments expropriate land from people (Home \& Lim, 2004). In Botswana, a rumour that his son was about to regularise family land angered one land owner: 'You are a crook, you could sell us with this yard, and leave us not knowing what is happening.' (Home \& Lim, 2004: 146).

While some research (e.g. Feder, 1985) have shown that land reform leads to increased productivity, others (e.g. Place \& Hazell, 1993; Place \& Otsuka, 2002; Migot-Adhola, Hazell, Blarel \& Place, 1991) suggest that private tenure does not increase farm productivity. The argument that larger, highly commercialised private farms are more efficient than smaller family farms has also been inconclusive, with some researchers like Dorward (1999) finding a positive link between farm size and productivity in Malawi, while others like Ünal (2008) and Rosset (1999) arguing that smaller farms are more productive than larger private farms. Apart from the farm size-productivity relationship, other reasons have been advanced to argue against larger commercial farms. Capital flight, for instance, is said to be at odds with the demands of local economies. Eckholm (1979) argues that towns surrounded by commercial farms normally die because of capital flight. While income/capital generated from smaller family farms normally circulates locally, income generated from larger commercial farmers is usually expatriated to benefit businesses in larger cities. Furthermore, the idea that high security of tenure stimulates increased investment is also contested by Pender et al. (2004, cited in Place, 2009) who did not find positive effect of titled land on investment in Uganda. Notwithstanding this, the idea that more 
investment will be realised following privatisation of land rights is still being used as one of the key arguments to support reforms in many parts of the world (Deininger, 2003). However, questions have been asked on whether it is the security of tenure that stimulates investment, or whether people invest in order to secure their rights (Place, 2009).

The argument that private land can promote land markets is equally inconclusive. Given the abundance of land in rural areas of many developing countries, land markets here may not be very well developed (Ubink \& Quan, 2008). Thus land markets can only be more visible in urban and peri-urban areas where pressure on land is very high due to commercial activity (Ng'ombe, Keivani, Mattingly \& Stubbs, in press; Place, 2009). On the environmental front, Rosset (1999) has gone beyond the economic motive supporting peasant farming, arguing that customary farms are a reservoir of ecological/environmental preservation as indigenous/peasant farmers have a vested interest in the environment as this can be a source of their livelihoods (e.g. herbal medicines). Because of this, their farming practices tend to be diverse, incorporating and preserving functional biodiversity on the farms. On the other hand, in private, large commercial farms, farmers use farming methods that do not seek to preserve ecosystems and the environment in general.

\section{Customary Land Reform in Zambia}

Although customary land reform in Zambia has a long history, the real effort to vigorously undertake the reform agenda as it is understood in contemporary literature can be said to have been initiated in 1991 following the introduction of the market economy. In the area of land administration, the ascension to power of the Movement for Multiparty Democracy (MMD) government in 1991 marked the end of monopolistic policies of President Kenneth Kaunda's socialistic regime and heralded the beginning of private sector-oriented land policy. This meant encouraging private ownership of land through issuance of individual titles. The policy was initially enshrined in the party's 1991 election manifesto which stated in part that 'the MMD shall institutionalise a modern, coherent, simplified and relevant land law code intended to ensure the fundamental right to private property and ownership of land...' (MMD, 1991: 7). The aim was to enact legislation that would restore investor confidence in the land market, attach economic value to undeveloped land, encourage private real estate agency business and promote the regular issuance of title deeds to more productive land owners in both rural and urban areas (Kajoba, 1998; Adams, 2003). It was not until 1995, however, that the government enacted the Lands Act as a step towards fulfilling the objectives already outlined in the party manifesto. The Act provided for, among other things, the conversion of customary tenure into leaseholds, an issue which has been controversial since the introduction of the policy (Brown, 2005). Since 1995, pieces of customary land have been converted into private property, although the circumstances under which some of the conversions have taken place have been suspicious as some traditional rulers have been found to enrich themselves by allocating land to outsider private investors at a fee at the expense of their subjects (Brown, 2005). In his research in Mungule area in Zambia's Chibombo District, Malambo (2013) found that of all the 219 title deeds that were issued in customary areas in April and July 2013, over 95\% were issued to non-customary residents i.e. to outsiders from cities within Zambia or even outside the country. In some areas, however, some chiefs and their subjects have been against the customary land reform agenda altogether for various reasons including the fact that this can undermine the rural political structure as chiefs are not chiefs without land. For a more detailed discussion on the historical perspective of land policy development and customary land reform in Zambia see for example Ng'ombe et al. (in press), Ng'ombe (2011) and Brown (2005).

\section{Methodology}

The findings discussed in this paper are based on a mixed methods approach, largely the international literature. Personal experience and fieldwork that was conducted in Zambia between September 2006 and February 2007, January 2009 and December 2013 complement the literature survey. In the case of empirical data, the study adopted a case study approach where two districts in North Western Province (Solwezi and Zambezi) were selected, with Nyakuleng'a and Mize (both in Zambezi) and Mushitala and Mumena (both in Solwezi) being the selected settlements. However, other respondents outside the above main case studies (like chief Kizela in Mufumbwe and proprietor of Kalundu Kangoma 
Farm in Monze town in Southern Province) were also considered. Chief Kizela was included at the request of the local council (Mufumbwe Distric Council) while the Kalundu Kangoma case was included because of its relevance to the objective of the study. The main method used was in-depth interviews with rural and peri-urban communities. All in all, 6 chiefs (3 in Solwezi, 2 in Zambezi and 1 in Mufumbwe) and 65 ordinary members of the community were interviewed. Participant observation and personal experience of the lead author gained whilst working as a Provincial Lands Officer in North-western province - and now working as a lecturer/researcher and extensively involved in research and customary land issues/chiefs in the studied locations - complemented the in-depth interviews.

\section{Findings}

Many writers (e.g. Kasanga \& Kotey, 2001; Ubink \& Quan, 2008; Agbosu, 2000; Amanor, 2004; Mulolwa, 2006) note that all land in customary areas is governed by native customs. The land holding group is the family, clan, village or community. Collective ownership is fundamental for social organization/interdependence, and provides a basis for equitable sharing of rural livelihoods. Each member of a society enjoys, freely, rights such as to bury (and to be buried), graze animals, pick fruits and collect firewood. These rights are mainly transferred by bequest as land sales in these areas are strongly discouraged because anthropologically land is seen as a gift from God; it does not have any monetary value (Ike, 1984). In a way, therefore, collective ownership of land acts as a shield against exploitation of man by man. Traditional chiefs play a very important role in the administration of land. They are entrusted with the duty to hold the land in perpetuity for and on behalf of their subjects (Amanor, 2004; Carino, 2006). People's perception about land is well summarised by the words of Ike (1984: 475): '[Land is] endowed with a sacred character... conceive[d] as a sort of deity who [is] the fount of fertility and guardian of public morality since it [is] witness to all transactions of man.'

For customary people, land is indeed the primary resource for all activities. Besides being perceived as the space on which man lives and farms to secure a livelihood (Leonard \& Longbottom, 2000), land is also considered to be the centre for all human relationships, values, language and ambitions (ibid); it is a source of all wealth, power, integrity and symbolism. Deininger (2003) adds that land is also associated with prestige and subsistence which are considered the primary economic goal by most rural communities. It is further noted by Deininger (2003) and Leonard and Longbottom (2000) that disputes over customary land are usually for the purpose of reconciliation as opposed to attempts to punish or pursue material redress from delinquents. In customary law, land cannot be owned by an individual. Therefore, the main ways by which an individual acquires the right to use customary land is largely by kingship, birth, and social contract (McAuslan, 2000). Land in customary areas is also considered to be the commodity that unites the past, the current and future generations. This is well elaborated by Chief Olsei of Odogbolu in Western Nigeria when he affirmed before the West African Land Commission in 1908 that: 'I conceive that land belongs to a vast family of which many are dead, few are living and countless are still unborn.' (quoted in Ike, 1984: 475). Another Nigerian chief (chief of Ife) put it this way:

We came from the ground and we have to go back to the ground and it is altogether out of place for anyone to think of selling the ground. They who are born and they who are yet unbegotten and they who are still in the womb require the means of support... (ibid, $475-476$ ).

As Ike (1984) notes, and as evidenced by the above quote, land in Africa is a sacred asset with strong ancestral ties; it is inalienable, and is to be passed on to the ancestors' posterity intact. As a result, other than working and harvesting from the land, it is enough for an individual to claim ownership of land by simply convincing that their ancestors are buried in that piece of land (Carino, 2006; Njoh, 2000). This is why, as Ike (1984) further notes, one's 'place of origin' is considered to be a place where they have not only physical but also spiritual roots. Tribal communities practise what Chikhwenda (2002) has called trusterty theory, whereby all property is owned by groups but used by individuals. The other striking feature attached to land is that he who clears the bush for purposes of cultivation establishes permanent rights to the cleared areas (Durning, 1992). 
The perception on land in Africa indicates that cultural beliefs have a significant impact on the way communities manage natural resources. In fact, this is endorsed by Article 26 of the United Nations Declaration on the Rights of Indigenous Peoples (UN, 2008) which, in recognition of the importance of culture and beliefs in rural land management practices, implores all governments to 'respect ... the customs, traditions and land tenure systems of the indigenous peoples.' Similarly, Article 13(1) of the International Labour Organisation (ILO) Convention no. 169 obliges governments '.. to respect the special importance for the cultures and spiritual values of the [indigenous] peoples of their relationship with the lands...in particular the collective aspects of this relationship.' Furthermore, the right to property is actually a human and peoples' right. This is provided for by Article 14 of the African Charter on Human and Peoples' Rights which states that "The right to property shall be guaranteed".

Schoffelleers (1979) provides that the belief that land belongs to the dead shows that there is a role played by ancestors in the administration of the resource. It is widely believed that the ancestors cannot allow complete land alienation, especially to outsiders, as this could lead to their descendants being deprived of their rights to enjoy the interests in land (Agbosu, 2000). Most traditional communities therefore believe that actions that violate this customary code of conduct have the potential to destroy the link between the past and future generations (Agbosu, 2000). Additionally, Agbosu (2000) asserts that the inability to comply with these rules can actually lead to ancestors' wrath on the wrongdoers. Amanor (2004) also adds that the fear of ancestors' wrath plays a fundamental role of maintaining custodial ethos in customary land administration across Africa. Regardless of this, however, in some developing countries especially Africa, land is still being indiscriminately allocated to strangers in the name of development - although in some cases these allocations are thwarted by communities in a bid to, among other things, preserve their culture (Amanor, 2004). In Ghana, for example, no land may be allocated to a stranger unless the ancestors sanction such allocations (Kasanga \& Kotey, 2001). This is achieved by making a sacrifice or performing a ritual like pouring libations (Ubink \& Quaran, 2008). This practice can be illustrated by the 1989 Filipino Mount Apo case in which Chief Tulalang Maway of the Lumad tribe and twenty of his subjects performed a sacred ritual (known locally as D'yandi) in protest of plans by the Philippine National Oil Company to execute a project on top of a volcanic mountain. The project aimed at tapping internal heat for generation of geothermal energy (Durning, 1992). The indigenous people refused to allocate the land to the oil company for the energy project because of the vow they made in the past to defend the sacred mountain. In that old vow, and as commanded by their Apotio (who they believed was the creator of the world), the indigenous people committed themselves, together with the future Lumad generations, to protect the mountain. Thus, we read:

Apotio told us, guard this place, never let anyone destroy or desecrate this place. You may suffer hardships and poverty, but never leave this place because this is where I live...Never give the mountain. It is better for you to die, to die rather than to give this mountain (ibid, 38).

Although indigenous land rights are governed by the head of a lineage, use of the land can be open to all other members of that lineage. Land markets are strongly discouraged as inheritance of rights to land is normally the most widespread form of land transfer. Every member of the society has unrestricted access to open access resources like collection of firewood. These longstanding ways of managing natural resources have had an impact on the way traditional political systems would receive policy change. For instance, the desire by traditional rulers to keep communities intact as a society explains why rural communities have a propensity to guard against change (Carino, 2006). But this is being undermined by the spread of globalisation/capitalism as customary land continues to be targeted for reform by both national governments and the international community to pave way for economic development. As a result, rural communities find themselves struggling to deal with the conflicts between the global demands and their local economic ambitions (Keivani \& Mattingly, 2007).

The preceding literature-based discussion can be consolidated by findings from Zambia's Zambezi and Solwezi Districts in North-western Province where the rural citizenry were found to be against land reform partly because of the 
fear that sanctioning the conversion of customary land to private property can anger their ancestors. Just as Kasanga and Kotey (2001) and others have noted, it is believed that ancestors in Zambia have an influence on how decisions on land should be made. Some respondents told us that some pieces of land are specifically reserved for the dead and as a result such land cannot be alienated to anybody. To emphasise this point, and after their traditional chief had authorised them, two villagers in Mize settlement took the research team on a guided tour of one of their most sacred places - the royal cemetery (see figure 1).

a) Exterior

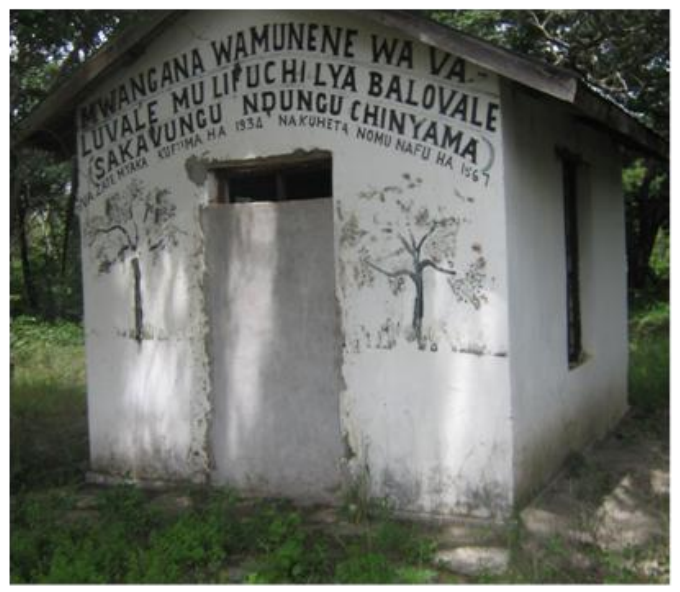

b) Interior

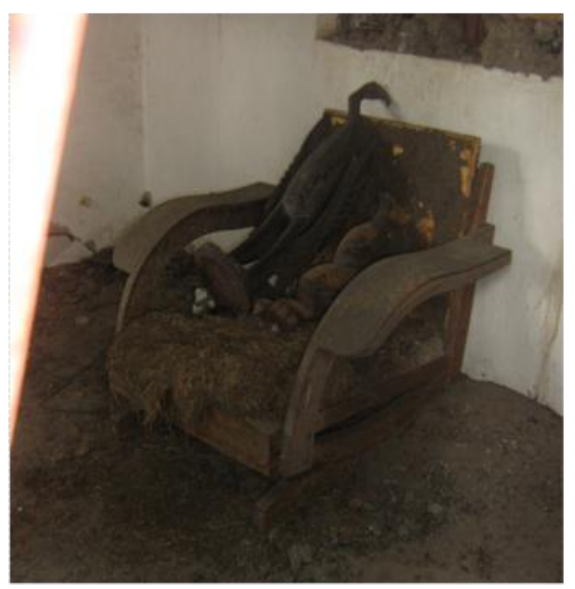

Figure 1. A Grave for Ndungu Chinyama, Chief of the Luvale People, 1934 - 67

Source: Field survey data, 2007

When these overlords pass on, a chair is placed inside the building that is built on top of the grave. As one of the cemetery tour guide disclosed during the tour (4 February 2007), the reason for placing a chair inside the grave building is the belief that the deceased chief should have somewhere to sit on and rest in his death. It was also further learnt from the same informant that it was locally believed that continued observance of these and other customs could earn the living souls many benefits, including regular rainfall, and hence guaranteed produce from land (e.g. harvest and wild fruits). With regards to land administration, the chiefs in the studied locations consider themselves to have a duty to manage the land in a proper, unselfish manner. In particular, land reserved for graves is highly respected and this cannot be given out to investors. However, if this is to be strictly respected then no portion of land may be given out at all because, according to some respondents like one retired headman in Nyakuleng'a settlement, the entire land in the area is a graveyard as it is home to millions of graves of ancestors that the current generation is not even aware of (interview 2 February 2007). This finding was also confirmed in December 2013 by two representatives from the Mumena Royal Establishment (Interview 8 December 2013). The following two cases further illustrate how traditional beliefs can influence land tenure/reform and administration. In the first case a ritual was performed in order to save a mine from flooding while in the second a ritual was performed to establish the cause of drought.

Case 1: Saving A Mine From Floods

In 1949, there were severe floods at Kansanshi Mine in Solwezi. The floods threatened the operations at the mine. Thus, they needed to be stopped if mining was to continue. The traditional rulers advised the mine management that the floods could only be stopped by performing a ritual. The ritual was to be performed by the chief in which the mine was located. However, there was a wrangle between chief Mulonga and chief Mujimanzovu regarding ownership of the land on which the mine was located. Both chiefs claimed that the 
mine was located in their chiefdom and as such it was them who were supposed to perform the ritual. In order to stop the floods, and thereby establish the true owner of the land in which the subject mine was located, a plant locally known as muyombo was planted by either chief. A song in memory of ancestors was sung. After a few days, Chief Mulonga's tree germinated, while that of Mujimanzovu died. The germination of the tree, it was believed by both chiefs and their subjects, signified ownership of the land in which the mine was located. Eventually, the floods stopped after the rightful chief performed further rituals.

Case 2. A Farm Owner Is Accused Of Causing Drought

In this particular case a foreign investor owned Kalundu Kangoma Farm on titled land. On this land was a very huge baobab tree that had been standing there for many years. According to the local villagers, some of whom were employees at the farm, the tree used to bring rain to the village. However, with intentions to commercialise his farming activities, the investor cut the tree. Unfortunately, the cutting of the tree seem to have coincided with a serious drought in the village that same year. As a result, and as they always do, the villagers needed to establish the cause of the drought in order to prescribe a correct remedy. A witch-hunt ritual was then performed $\mathrm{ku}$ malende (at a shrine). Songs of praising ancestors were sung, after which it was discovered by a spiritually-possessed woman diviner that the drought was caused by the cutting by the investor of the sacred baobab tree. It was alleged that the ancestors were annoyed with the investor and his action. A sacrifice was then performed, although it was not clear whether this was followed by rains.

While findings from the Kalundu Kangoma Farm may not add significant material to issues about conversion of customary land as this particular land was never converted (because, according to the owner, the land was acquired in 1948 when customary land conversion policy was not yet in place in the country), the case is serendipitous as it provides compelling evidence on how cultural beliefs can sometimes shape the attitudes of rural communities towards private tenure and investment. With such conflicting belief systems between the elite investors and the illiterate peasantry, achieving economic development and/or poverty alleviation through the sought-after replacement of traditional tenure with state tenure as documented in contemporary literature and espoused by the international community and governments becomes a huge challenge. As noted by Ng'ombe and Keivani (2013), however, while the reliability of these traditional cultures and belief systems may be debatable, they can nonetheless affect the way rural communities would accept agendas that seek to transform customary land tenure into private property.

Another key finding from the fieldwork in North-western province is that customary communities are reluctant to have their land converted to private land because after they convert the land to private property, the investors cease to respect the local traditional rulers, let alone 'feeding our chief because according to our culture our chief needs to be fed because he does not work his farm. If he works his farm, when is he going to find time to govern his people?' [interview with Kalombo Makayi (pseudonym) in Mumena, Solwezi, December 2013]. This opinion was very common in all the studied settlements, especially the more rural ones. In Nyakuleng'a, for example, all the respondents (interviews February 2007) confirmed that after harvest each subject was expected to donate to their chief a portion of their produce, something the respondents argued that the outsider private land owners would most likely fail to honour as these would now be answerable to the central government where they would be statutorily required to be paying ground rent and land taxes.

\section{Discussion and Concluding Remarks}

Land in customary areas still assumes its classic role of a tribal asset which is crucial for the survival of society as a whole and as such should be preserved for and passed on to posterity intact. The role of ancestors in land management in customary areas is still manifest, with many people believing that they are just trustees and not owners of the land. These beliefs need to be taken into consideration in the pursuit of communal land reform because they shape the opinion of communities about private tenure regimes, thereby having an effect on people's opinion on whether or not to 
accept customary land reform. As once remarked by one Nigerian chief as discussed in this paper, land in rural areas is thus still considered to belong to a large family comprising the dead, the living and those yet to be born. This suggests that the ancestors are believed to have a role to play in land management. For instance, the ancestors would not permit any absolute alienation of land to an individual. Doing so would deprive future generations, as well as severing the link between them, the living and the dead (Ike, 1984). Thus any decision on communal land must absolutely be made in the interest of the community at large. Compliance with these rules is partly enforced by the fear of the ancestors' wrath on the offenders (Agbosu, 2000). Because of this, certain customary lands are believed to be too sacred and of too high sentimental value to be allocated to anybody - allocating such land is akin to committing sacrilege and may require sanctifying the land, while other lands can only be allocated after performing some rituals (e.g. pouring libation) and 'consulting' the ancestors.

The role of ancestors in land tenure and administration is not only evident in Zambia. Kelly and Francis (1994) document some of the most sacred places/lands of the American Indians (the Navajos). The authors also outline the crucial role the ancestors, rituals, witchcraft and other forms of traditional beliefs play in land tenure and administration within the Navaj communities. Some commentators like the World Bank (van den Brink, Thomas, Binswanger, Bruce \& Byamugisha, 2006) have shown how witchcraft in rural Africa has a bearing on land tenure and administration. The Bank argues that the reason why some customary landholders may be against private tenure is partly because 'successful investment on land excites jealousy, both on the part of traditional rulers and among neighbours, and can result in [accusations of] witchcraft of which the punishment to the offender may include expulsion [from the village]' (p. 13).

The foregoing discussion shows how traditional beliefs can and actually do affect land tenure and administration in customary areas of Africa. While the validity of these beliefs may be subject to debate, what is evident is that the beliefs affect the way societies could receive any land policy interventions. As such, the beliefs shape their lives and eventually have a bearing on how the rural citizens may perceive governments' efforts to modernise land tenure. Thus, as highlighted by Bryant's (1996) study of land reform in Brazil, there is need for land reformers to focus not only on economic and environmental but also cultural/institutional issues associated with land reform. Therefore, land reform should be executed with a clear awareness and understanding of people's traditional beliefs and institutions as these may be a constraint to the success of the reform programme and consequently economic growth and sustainable development. As remarked in the Kari-Oca Declaration at a summit held in Brazil on 30 May 1992, the indigenous peoples 'walk to the future in the footprints of [their] ancestors' (Kimberley Declaration, 2002: 1), and as such land reform intervention efforts should seek to embrace the belief echoed in this declaration especially in rural Africa where indigenous people's way of life is highly entrenched in these beliefs. This, therefore, reemphasises the point that while economic and environmental considerations are necessary in land (policy) reform, they are not enough. These cultural considerations are equally important in rural Africa setting because, as one chief in this study explained, 'land as you know is our integrity; land is our power. We are what we are today because of land. All these battles that we fought in the past were because of land' (interview with chief MN, 12 February 2007). In fact, disregarding these cultural and ancestral beliefs when expropriating traditional land is against the international law such as Article 13(1) of the ILO Convention no. 169 (ILO, 1989) which obliges governments '....to respect the special importance for the cultures and spiritual values of the peoples concerned of their relationship with the lands...in particular the collective aspects of this relationship.'

\section{References}

Adams, M. (2003). Land tenure policy and practice in Zambia: Issues relating to the development of the agricultural sector. Draft document for DfID. Oxford: Mokoro.

Agbosu, L. K. (2000). Land law in Ghana: Contradiction between Anglo-American and customary conceptions of tenure and practices. Land Tenure Center working paper 33, University of Wisconsin, Madison. 
Amanor, K. (2004). Global and local land markets: The role of the customary. In Land in Africa: Market asset or secure livelihoods? eds. Julian Quan, Su Fei Tan and Camilla Toulmin, Proceedings and summary of conclusions from the Land in Africa Conference held in London November 8 - 9, 2004. London: IIED.

Barnes, G. (1986). Cultural dynamics and emerging land information needs. Wisconsin: University of Wisconsin.

Barrows, R. \& Roth, M. (1990). Land tenure and investment in African agriculture: Theory and evidence. Journal of Modern African Studies 28(2): 265 - 97. http://dx.doi.org/10.1017/S0022278X00054458

Borras, S. M. jr. (2005). The underlying assumptions, theory, and practice of neoliberal land policies. Land Research Action Network: http://www.landaction.org/display.php?article=328.

Borras, S. M. jr. (2002). Towards a better understanding of the market-based agrarian reform in theory and practice: Focussing on the Brazilian case. Land Reform, Land Settlement and Cooperatives 2002, 1, 32 - 50.

Brinkerhoff, D. W. (1996). Process perspectives on policy change: Highlighting implementation. World Development 24(9) 1395 - 1401. http://dx.doi.org/10.1016/0305-750X(96)00056-3

Brown, T. (2005). Contestation, confusion and corruption: Market-based land reform in Zambia.

http://www.oxfam.org.uk/what_we_do/issues/livelihoods/landrights/downloads/market_based_land_reform_zambi a.pdf.

Bruce, W. J, Kachamba, F. \& Hansungule, M. (1995). Land administration and constraints. In Land tenure, land markets, and institutional transformation in Zambia, eds. Michael Roth with Stephen G. Smith. Madison: University of Wisconsin.

Bryant, C. (1996). Strategic change through sensible projects. World Development 24(9), $1539-50$. http://dx.doi.org/10.1016/0305-750X(96)00057-5

Carino, J. K. (2006). Ancestral land, food sovereignty and the right to self-determination: Indigenous people's perspectives on agrarian reform. Contribution to the Civil Society Issue Paper "Land, territory and dignity", for the International Conference on Agrarian Reform and Rural Development (ICARRD), 7 - 10 March 2006, Porto Alegre, Brazil.

Chikhwenda, E.J.W. (2002). Transactive land tenure system in the face of globalisation in Malawi. Paper presented at the 9th IASCP (International Association for the Study of Common Property) Biennial Conference The commons in the age of globalisation 17 - 21 June 2002, Victoria, Zimbabwe.

Cotula, L. (2004). Securing the commons in an era of privatisation: Policy and legislative challenges. In Land in Africa: Market asset or secure livelihoods? eds. Julian Quan, Su Fei Tan and Camilla Toulmin, Proceedings and summary of conclusions from the Land in Africa Conference held in London November 8 - 9, 2004. London: IIED.

Deininger, K. (2003). Land policies for growth and poverty reduction. Washington, D.C: World Bank.

de Soto, H. (2000). The mystery of capital: Why capitalism triumphs in the West and fails everywhere else. New York: Basic Books.

DfID (Department for International Development). (2007). Land: Better access and secure rights for poor people. London: DfID.

Dorward, A. (1999). Farm size and productivity in Malawian smallholder agriculture. Journal of Development Studies 35(5), 141 - 161. http://dx.doi.org/10.1080/00220389908422595

Durning, A. T. (1992). Guardians of the land: Indigenous peoples and the health of the earth. Washington, D.C: Worldwatch Institute.

Eckholm, E. (1979). The dispossessed of the earth: Land reform and sustainable development. Washington, D.C: Worldwatch Institute.

Feder, G. (1985). The relationship between farm size and farm productivity: The role of family labour, supervision and credit constraints. Journal of Development Economics 18(2-3), 297-313. http://dx.doi.org/10.1016/0304-3878(85)90059-8

Hardin, G. (1968). The tragedy of the commons. Science 162(3859), 1243-48 http://dx.doi.org/10.1126/science.162.3859.1243

Home, R. \& Hilary, L. (2004). Introduction: Demystifying 'The mystery of capital'. In Demystifying the mystery of capital: Land tenure and poverty in Africa and the Caribbean, eds. Robert Home and Hilary Lim. London: GlassHouse. 
Ike, D. N. (1984). The system of land rights in Nigerian agriculture. American Journal of Economics and Sociology 43(4), 469 - 80. http://dx.doi.org/10.1111/j.1536-7150.1984.tb01875.x

ILO (International Labour Organisation). (1989). Convention Concerning Indigenous and Tribal Peoples in Independent Countries, No. 169. ILO, Geneva.

Kajoba, G. M. (1998). The landmarks of Zambia's land tenure system: From protectionalism to empowerment. Proceedings of the International Conference on Land Tenure in the developing world with a focus on Southern Africa, University of Cape Town, South Africa.

Kasanga, K. \& Kotey, N.A. (2001). Land management in Ghana: Building on tradition and modernity. London: International Institute for Environment and Development (IIED).

Keivani, R. \& Mattingly, M. (2007). The interface of globalisation and peripheral land in the cities of the South: Implications for urban governance and local economic development. International Journal of Urban and Regional Research 31(2), 459 - 74. http://dx.doi.org/10.1111/j.1468-2427.2007.00718.x

Kelley, K. \& Harris, F. (1994). Navajo sacred places. Bloomington: Indiana University Press.

Kimberley Declaration (2002). Kimberley Declaration. International indigenous peoples summit on sustainable development, 20 - 23 August 2002, Kimberly, South Africa.

Leonard, R. \& Longbottom, J. (2000). Land tenure lexicon: A glossary of terms from English and French speaking West Africa. London: International Institute for Environment and Development (IIED).

Malambo H.A. (2013). Land administration in Zambia since 1991: History, opportunities and challenges. Global Advanced Research Journal of History, Political Science and International Relations 2(4), 53- 66.

Manji, A. (2006). The politics of land reform in Africa: From communal tenure to free markets. London: Zed Books.

McAuslan, P. (2000). Only the name of the country changes: The diaspora of "European" land law in Commonwealth Africa. In Evolving land rights, policy and tenure in Africa, eds. Camilla Toulmin and Julian Quan. London: DfID/IIED/NRI.

Migot-Adholla, S., Hazell, P., Blarel, B. \& Place, F. (1991). Indigenous land rights systems in sub-Saharan Africa: A constraint on productivity? World Bank Economic Review 5(1), 155 - 75.

MMD (Movement for Multiparty Democracy). (1991). MMD election manifesto. Lusaka: MMD.

Mulolwa, A. (2006). Demystifying customary tenure in Zambia. Paper presented at the 5th FIG conference Promoting land administration and good governance, March 8 - 11, in Accra.

Ng'ombe, A. (2011). Modernisation of land tenure in Zambia: Focus on the privatisation of customary land rights (Unpublished doctoral thesis). Oxford Brookes University, Oxford, UK.

Ng'ombe, A. \& Keivani, R. (2013). Customary land reform to facilitate private investment in Zambia: achievements, potential and limitations. Urban Forum 24(1), 33 - 48. http://dx.doi.org/10.1007/s12132-013-9188-y

Ng’ombe, A., Keivani, R., Mattingly, M. \& Stubbs, M. (in press). Impacts of privatisation of customary land rights in Zambia: A comparative study of rural and peri-urban locations. International Journal of Urban \& Regional Research.

Njoh, A. J. (2000). Continuity and change in Cameroon land policy. Planning Perspectives 15(3) $241-65$. http://dx.doi.org/10.1080/026654300407454

Payne, G., Durand-Lasserve, A. \& Rakodi, C. (2009). The limits of land titling and home ownership. Environment and Urbanisation, 21(2): 443 - 62. http://dx.doi.org/10.1177/0956247809344364

Place, F. (2009). Land tenure and agricultural productivity in Africa: A comparative analysis of the economics literature and recent policy strategies and reform. World Development 37(8), 1326- 36. http://dx.doi.org/10.1016/j.worlddev.2008.08.020

Place, F. \& Hazell, P. (1993). Productivity effects of indigenous land tenure systems in sub-Saharan Africa. American Journal of Agriculture Economics 75, 10 - 19. http://dx.doi.org/10.2307/1242949

Place, F. \& Otsuka, K. (2002). Land tenure systems and their impacts on agricultural investments and productivity in Uganda. Journal of development studies 38(6) 105 - 28. http://dx.doi.org/10.1080/00220380412331322601

Quan, J. (2008). Land reform and rural territories: Experiences from Brazil and South Africa. IIED gatekeeper series, 134: February 2008. 
Rosset, P. (1999). The multiple functions and benefits of small farm agriculture: In the context of global trading negotiations. Food First Policy Brief No. 4. Oakland: Institute for Food and Development Policy.

Schoffeleers, J.M. (ed.) (1979). Guardians of the land: Essays on Central African territorial cults. Gwelo: Mambo Press.

Ubink, J. M. (2008). Negotiated or negated? The rhetoric and reality of customary tenure in an Ashanti village in Ghana. Africa 78(2): 264 - 87. http://dx.doi.org/10.3366/E0001972008000168

Ubink, J.M. \& Quan, J.F. (2008). How to combine tradition and modernity? Rethinking customary land management in Ghana. Land Use Policy 25(2) 198 - 213. http://dx.doi.org/10.1016/j.landusepol.2007.06.002

UN (United Nations). (2008). Declaration on the rights of indigenous peoples. Resolution 61/295 of 13 September 2007. Geneva: United Nations.

Ünal, F. G. (2008). Small is beautiful: Evidence of an inverse relationship between farm size and yield in Turkey. Working Paper no. 551, The Levy Economics Institute of Bard College at Simon's Rock.

van den Brink, R., Thomas, G., Binswanger, H., Bruce, J. \& Byamugisha, F. (2006). Consensus, confusion, and controversy: Selected land reform issues in sub-Sahara Africa. World Bank Working Paper 71, Washington, D.C: World Bank.

van der Molen, P. (2002). The dynamic aspect of land administration: An often forgotten component in system design. Computers, Environment and Urban Systems 26(5) 361- 81.

van Hecke, J. (2001). A European perspective on land reform in southern Africa. In Land reform in Southern Africa, Proceedings and conclusions of a conference held 24 - 26 May 2001, Johannesburg, South Africa.

\section{$(c c)$ EY}

This work is licensed under a Creative Commons Attribution 3.0 License. 